\title{
Histopathological features of infections caused by Fusarium oxysporum and $F$. solani in purple passionfruit plants (Passiflora edulis Sims)
}

\author{
Emiro Ortiz ${ }^{1}$, Marisol Cruz², Luz Marina Melgarejo², Xavier Marquínez ${ }^{3}$, Lilliana Hoyos-Carvajal ${ }^{1}$
}

${ }^{1}$ Facultad de Ciencias Agrarias, Universidad Nacional de Colombia; ${ }^{2}$ Laboratorio de Fisiología y Bioquímica Vegetal, Departamento de Biología, Facultad de Ciencias, Universidad Nacional de Colombia; ${ }^{3}$ Laboratorio de Anatomía y Cultivo de Tejidos Vegetales, Departamento de Biología, Facultad de Ciencias, Universidad Nacional de Colombia

Autor para correspondência: Lilliana Hoyos-Carvajal (limhoyosca@unal.edu.co)

Data de chegada: 02/08/2013. Aceito para publicação em: 20/03/2014.

$10.1590 / 0100-5405 / 1910$

\begin{abstract}
Ortiz, E.; Cruz, M.; Melgarejo, L.M.; Marquínez, X.; Hoyos-Carvajal, L. Histopathological features of infections caused by Fusarium oxysporum and $\boldsymbol{F}$. solani in purple passionfruit plants (Passiflora edulis Sims). Summa Phytopathologica, v.40, n.2, p.134-140, 2014.

The purple passionfruit plant, Passiflora edulis Sims, ranks second in fruit exportation in Colombia, and its main destination is the European market. However, its production is affected by several diseases, including fusariosis. This paper presents the histopathological features of different tissues affected by the pathogens Fusarium oxysporum and Fusarium solani. Both microorganisms produce similar responses on the plant: colonization of xylem vessels by hyphae

and microconidia, hypertrophy and hyperplasia of the cambium, xylem and phloem; destruction of xylem fibers and amyloplasts in parenchymatous cells; and production of gels by the plant. However, there are differences in the colonization mechanism, F. solani penetrates and is concentrated especially at the collar zone, while F. oxysporum penetrates the roots and moves through the vascular system to colonize the plant.
\end{abstract}

Additional keywords: Passiflora edulis Sims, F. oxysporum, F. solani, histopathology, colonization.

\section{RESUMO}

Ortiz, E.; Cruz, M.; Melgarejo, L.M.; Marquínez, X.; Hoyos-Carvajal, L. Características hispatologicas da infecção causada por Fusarium oxysporum e F. solani em maracujá-roxo (Passiflora edulis Sims). Summa Phytopathologica, v.40, n.2, p.134-140, 2014.

O maracujá roxo Passiflora edulis Sims., destaca-se posicionado em segundo lugar na exportação de frutas da Colômbia, cujo mercado europeu é o principal destino. No entanto, a produção é afetada por várias doenças, incluindo a presença de fusariose. Este trabalho apresenta as características histopatológicas de diferentes tecidos afetados elos patógenos Fusarium oxysporum e Fusarium solani. Ambos os organismos produzem efeitos semelhantes sobre a planta: colonização dos vasos do xilema por hifas e microconídios, hipertrofia e hiperplasia do câmbio, xilema e floema; destruição de fibras do xilema e amiloplastos em células parenquimatosas, também a produção de géis pela planta. No entanto, existem diferenças no mecanismo de colonização, $F$. solani entra e se concentra principalmente na área do colo enquanto $F$. oxysporum penetra nas raízes e movese através do sistema vascular para colonizar a planta.

Palavras-chave adicionais: Passiflora edulis Sims., F. oxysporum, F. solani, histopatologia, a colonização.

The purple passionfruit plant (Passiflora edulis Sims) belongs to the family Passifloraceae and the fresh fruit is an important Colombian exportation product. Unfortunately, phytosanitary problems impose or result in important limiting factors for the quality and/or quantity of exported passion fruits (5).

Fusarium wilt caused by $F$. oxysporum and collar rot caused by $F$. solani are among the diseases associated with wilt (15). These two diseases have similar symptoms, which may cause confusion in diagnosis (9). In both cases, there is mild leaf chlorosis and unequal drying of the aerial parts in the early stages of infection. The symptoms become more severe later, when the leaves fall down and the vascular system turns from brown to red, eventually leading the plant to death. Collar rot leads to widespread necrosis of 2 to $10 \mathrm{~cm}$ width at the collar of the plant, where small, red points corresponding to the pathogen perithecia can eventually be observed (20).

Regarding the mechanism of infection, $F$. oxysporum produces hyphae that directly penetrate the root epidermal walls (13). Then, the mycelium intercellularly advances through the root cortex until the xylem vessels, which it uses as a pathway for rapid colonization of the host, particularly by means of microconidia (4). Wilt symptoms result of severe water stress, especially due to the blockage of vessels. This process involves fungal mycelium accumulation, toxin production and host-defense responses, which include the production of gels, tyloses, and proliferation of parenchyma cells (2).

Although several studies have focused on the histological response of different hosts to infection by $F$. oxysporum and $F$. solani, little information is currently available about these interactions with Passifloraceae plant species reported as susceptible to Fusarium wilt $(10,12,18$ and 19) and collar rot (6, 8, 17 and 21). Only Emchembe and Mukiibi (1976, cited by 19) reported that invasion and colonization of the cortical parenchyma and the xylem occur or emerge in the tissues of passionfruit plants affected by Nectria haematococca (F. solani). 
Based on the limiting conditions of fusariosis for purple passionfruit plants and the lack of knowledge in the area of pathology needed to establish effective methods to manage this disease, the aim of this study is to determine the histopathological features of purple passionfruit plants infected with $F$. oxysporum and $F$. solani, contributing to the literature by providing descriptions of the distribution of each pathogen in different plant tissues, their colonization, and the tissue alterations that the infection produces in the plant.

\section{MATERIALS AND METHODS}

The processed tissue samples from purple passionfruit plants from commercial seeds had natural and induced infection with $F$. oxysporum and F. solani in the root, collar and stem. Sections were obtained from a naturally infected nine-month crop. These plants were found in the area of Venecia (Cundinamarca, Colombia), located at $4^{\circ} 01^{\prime} 41.8^{\prime \prime}$ (latitude N), 74³1'17.7' (longitude W), and 1794 meters above the sea level.

To analyze artificially inoculated tissues, 2- and 4-month-old plants were inoculated with strains of $F$. oxysporum (codes A54, A64) and F. solani (code A62), respectively. These strains were isolated from purple passionfruit plants (15) and deposited in the Plant Clinic Laboratory of Universidad Nacional de Colombia. Plants were cultivated in the greenhouse of the Faculty of Agronomy, Universidad Nacional de Colombia, Bogotá (average temperature of $25^{\circ} \mathrm{C}$ and relative humidity of $70 \%$ ). F. oxysporum was inoculated by immersing roots without wounds in a conidial suspension produced in liquid malt extract media (MS), at a concentration of $1 \times 10^{6}$ conidia / $\mathrm{mL}$ (10 and 25 modified). F. solani was inoculated by the direct contact between young mycelium disks developed on potato dextrose agar (PDA) and the plant collar showing small induced incision (8 and 18). Samplings occurred once symptoms arose, at $37 \mathrm{dpi}$ (days post inoculation) for $F$. oxysporum and at 90 dpi for F. solani. In both cases, histological analyses were performed for sections of the root, the collar and the stem. Simultaneously, pathogens were re-isolated in PDA to confirm the disease causality.

Sections were fixed in FAA ( $10 \%$ formalin $-5 \%$ acetic acid $-85 \%$ alcohol to 70\%) for $24 \mathrm{~h}$, dehydrated in an EtOH series (70, 80, 85, 90, $96 \%$ and absolute EtOH) for $24 \mathrm{~h}$ each and rinsed in $100 \%$ terbutanol for $24 \mathrm{~h}$. They were subsequently embedded in a mixture of terbutanol: paraffin $1: 1 \mathrm{v} / \mathrm{w}$ and later in pure paraffin (Paraplast plus paraffin at $60^{\circ} \mathrm{C}$ ), for a $24 \mathrm{~h}$ period per pass. Finally, the blocks containing the samples were sectioned in a rotational microtome Minot-type model 820 Spencer (American Optical, Delhi) (7).

For the staining process, different techniques were tested: (a) safranin - fast green (7), (b) periodic acid - Schiff reagent (PAS) (1), with the modification of including a contrast with fast green for 2 segunds; and (c) astra blue - basic fuchsin double staining (11).

\section{RESULTS}

\section{Anatomy of healthy tissues of purple passionfruit plants}

Cross-sections of the stem of 18-week-old plants (Figure 1A) evidenced monostratified epidermis constituted of polygonal cells covered by a thinner cuticle; the cortex is formed by one or two layers of collenchyma, six to eight layers of parenchyma and sporadic presence of amyloplasts and drusen. The primary vascular system is eustele; however, at this development stage, plants show secondary growth. The cambial zone consists of three or four rows of isodiametric cells; the secondary xylem is arranged in more or less defined rows, containing large vessels of approximately 105 to $160 \mu \mathrm{m}$ in diameter, abundant radial and paratracheal parenchyma with lignified walls and evident amyloplasts, tracheids and occasional xylem fibers. The primary xylem presents non-lignified parenchyma and vessels of smaller diameter, as well as internal limits of the pith, which ends in a central cavity. The primary and secondary phloems are externally limited by periphloematic fibers and peripherally spaced in packages by ray parenchyma cells. The phloem (Figure 1B) is characterized by larger sieve cells and smaller companion cells.

The transverse section of the collar (Figure 1C) evidenced histological distributions similar to those described for the stem, in which the epidermis is replaced by the periderm (cork, phellogen and phelloderm) and lenticels are frequent; the ray parenchyma cells have numerous amyloplasts, which produce differential staining according to the used technique (Figure 1D, E). In addition to the vessels and ray parenchyma, there are a large number of xylem fibers with conspicuous secondary walls (Figure 1D, E). The central region is characterized by the presence of a compact pith made up of parenchyma cells.

Roots with secondary growth are characterized by the presence of a parenchymatic secondary cortex, which have the outermost cells displaying cell division and incipient wall lignification (exodermis), even without phelloderm formation. The secondary phloem is not externally limited by periphloematic fibers as in the stem. In the secondary xylem, fibers and tracheids are abundant and bounded by ray parenchyma cells as in the collar (Figure 1F). In the center, there is no pith. Instead, the primary xylem reveals that the primary roots are diarchic.

The effect of each stain on the different cellular types within each tissue can be compared based on Figure 1 D-F. Xylem vessels are easily recognized with all types of staining due to their characteristic size and common absence of content. Xylem parenchyma cells are recognized in all cases due to their cytoplasmic content. The latter is rich in amyloplasts, which change color depending on the polysaccharide interaction with the specific dye. When PAS is used, the tissue produces intense magenta stain (Figure 1D) due to reactions of the polysaccharides with the periodic acid and Schiff's reagent (7); however, when Astra blue - basic fuchsin stain is employed, the tissue acquires a light pink translucent appearance (Figure 1E), similar to that reported by Kraus et al., 1998 (11). Safranin - fast green stain results in a light green tissue (Figure 1F), which is due to the cytoplasm mark (7).

\section{Histopathology of infections caused by $F$. oxysporum on the tissues of purple passionfruit plant (Fusarium wilt)}

As shown in Figure 2, cross sections of collar (A, B), stem (C and $\mathrm{D})$, and root (E and F) of plants inoculated with $F$. oxysporum (37 dpi) evidences the presence of the pathogen colonizing xylem vessels and ray parenchyma. Some xylem vessels are significantly colonized by hyphae and microconidia of the pathogen, which becomes more evident under up to $100 \mathrm{X}$ magnification (Figure 2, A-C). Fungal structures can also be seen due to the absence of amyloplasts in ray parenchyma cells and the significant degradation of xylem fibers, compared to healthy tissues, as well as due to the production of gels (Figure 2B) as a defense mechanism of the plant (2). Gels and pathogen structures were differentiated by the contrast obtained between staining with astra blue - basic fuchsin, which turns the polysaccharides present in the cell wall into blue, and staining with a dye, which makes the suberized or cutinized structures red (11). Therefore, the pathogen structures were stained blue due to the presence of chitin and glucan in the cell wall, 

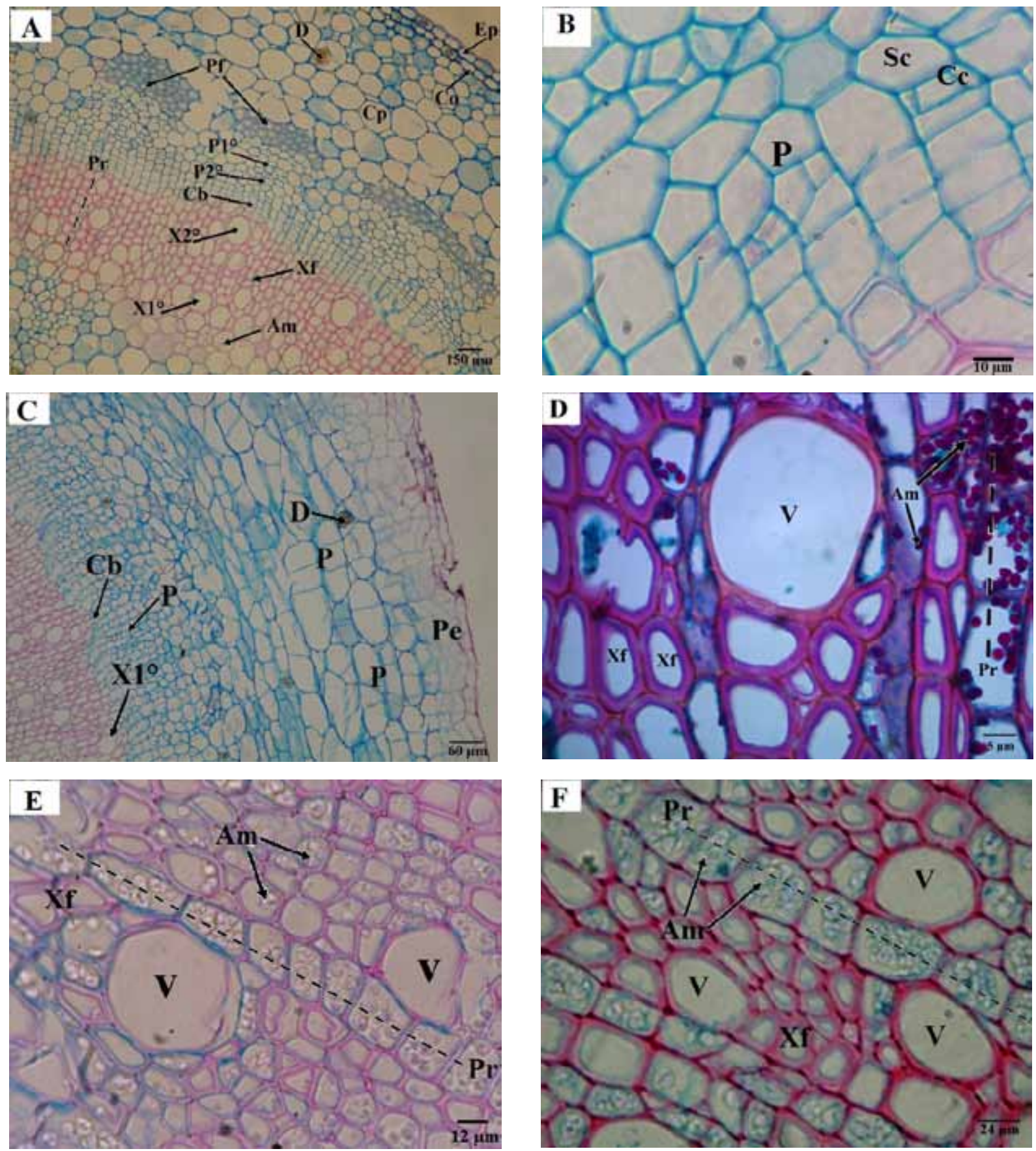

Figure 1. Transverse section of healthy tissue from purple passionfruit plants. Stem (A, B), collar (C, D, E) and root (F). A, B, C, E: astra blue basic fuchsin doublestaining; D: periodic acid - Schiff reactive (PAS); F: safranin - fast green. Ep, epidermis; Co, collenchyma; Cp, cortical parenchyma; Pf, periphloematic fibers; Cb, cambium; $\mathrm{X}^{\circ}$, primary xylem; $\mathrm{X} 2^{\circ}$, secondary xylem; $\mathrm{P}^{\circ}$, primary phloem, $\mathrm{P} 2^{\circ}$, secondary phloem, $\mathrm{V}$, vessel; $\mathrm{Pr}$, ray parenchyma cells; Xf, xylem fibers; Am, amyloplasts; D, druse; P, phloem; Sc, sieve cell; Cc, companion cell; Pe, periderm. A, C: 10X; B, D: 100X; E, F: 40X.

while the gels were stained red, suggesting polymerization processes with suberizant- or lignificant-type agent polyphenols (3).

For the phloem (Figure 2D), it is noteworthy that there was generalized disruption of all cells and cell shape loss, which is associated with hypertrophy and hyperplasia. As a result, sieve cells, companion cells and phloem parenchyma could not be identified (compare to Figure 1B).

Cross-sections of mature roots indicate stronger presence of pathogen structures in the vessels and parenchyma than in the stem and collar. There were also changes in the shape of xylem fiber cell walls and presence of gels in the vessels (Figure $2 \mathrm{E}, \mathrm{F}$ compare to Figure 1F). Microconidia have well-defined ellipsoidal shape and are abundant in the vessels (Figure 2C), while hyphae are presented as individual cylindrical filamentous structures colonizing vessels and ray parenchyma cells (Figure 2A) or grouped with microconidia obstructing xylem vessels (Figure 2A, B). 

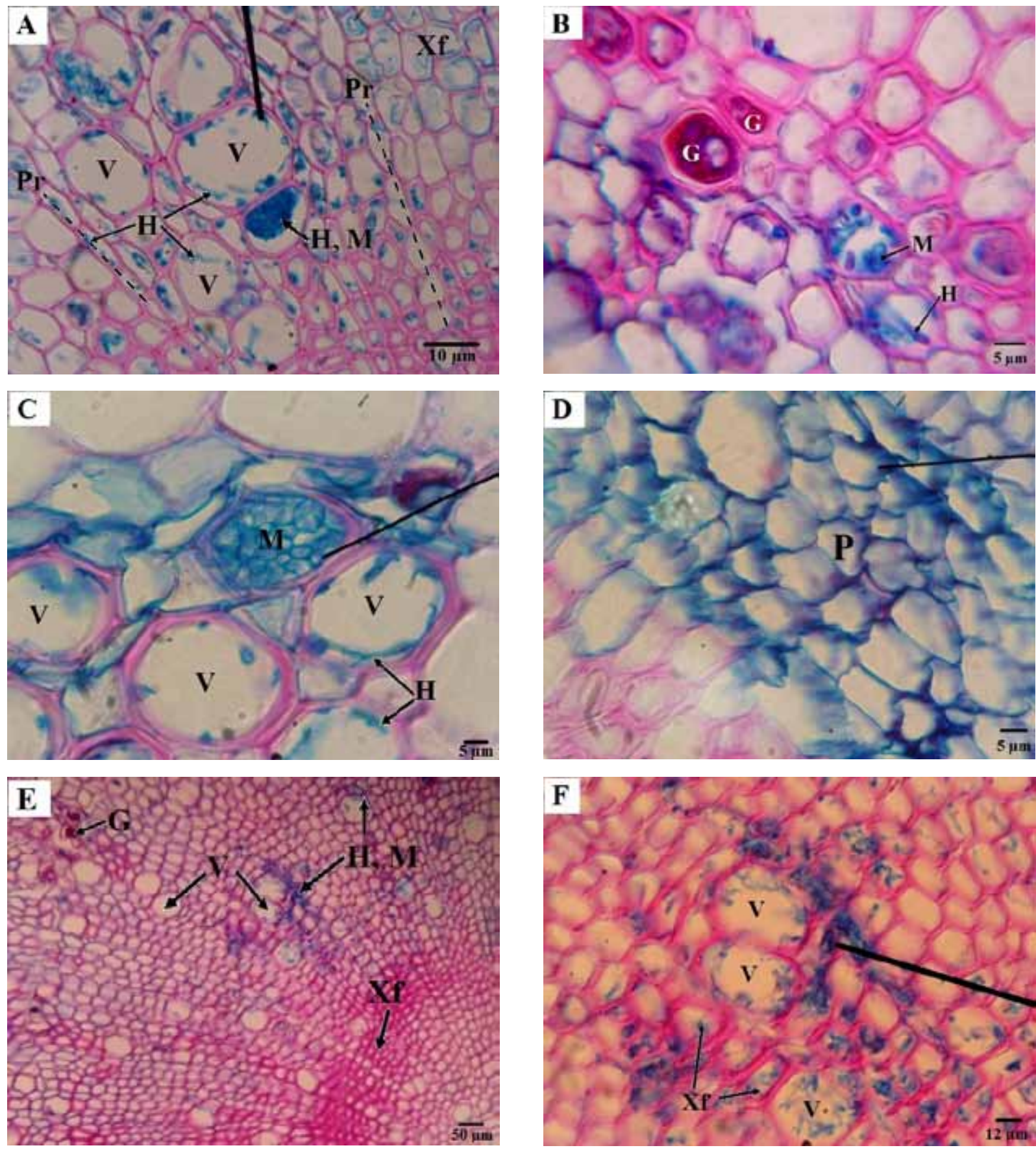

Figure 2. Infections induced by F. oxysporum on seedlings of purple passionfruit plants at 37 dpi. Cross-sections of collar (A, B), stem (C, D) and root (E, F). AF, astra blue-basic fuchsin double staining. The tip of the indicator shows hyphae (A), xylem vessel occluded by microconidia (C), alterations in phloem (D), hyphae and microconidia (F). V, xylem vessel; Pr, ray parenchyma cells; Xf, xylem fibers; P, phloem; H, hyphae of F. oxysporum; M, microconidia of F. oxysporum; G, gel. A-D: 100X; E: 10X; F, 40X.

\section{Histopathology of infections caused by $F$. solani on the tissues of purple passionfruit plant (collar rot)}

Cross-sections of collar tissue samples from purple passionfruit plants showing natural infection (Figure 3A-D) evidenced profuse pathogen colonization of periderm tissues, containing structures corresponding to conidiophores and microconidia on the epidermis (Figure 3A). Those cells that were dyed brown (Figure 3B, C) reveal a pattern of progression through the parenchyma, showing marked disruption and lack of differentiation due to the processes of hypertrophy and hyperplasia. The lumen of xylem vessels in the collar revealed the presence of the pathogen hyphae (Figure 3D) and, as a defense mechanism of the plant, there is abundant production of gels, often associated with hyphae. In contrast, pathogen structures could not be observed for the stem cuttings, but the presence of fewer gels could be noted (Figure 3E). For the root cuttings, there was no evidence of pathogen colonization; however, the amount of gels in the vessels was large (data not shown). PAS staining allowed clear differentiation of gels, which were stained intense fuchsia, thereby corroborating the 

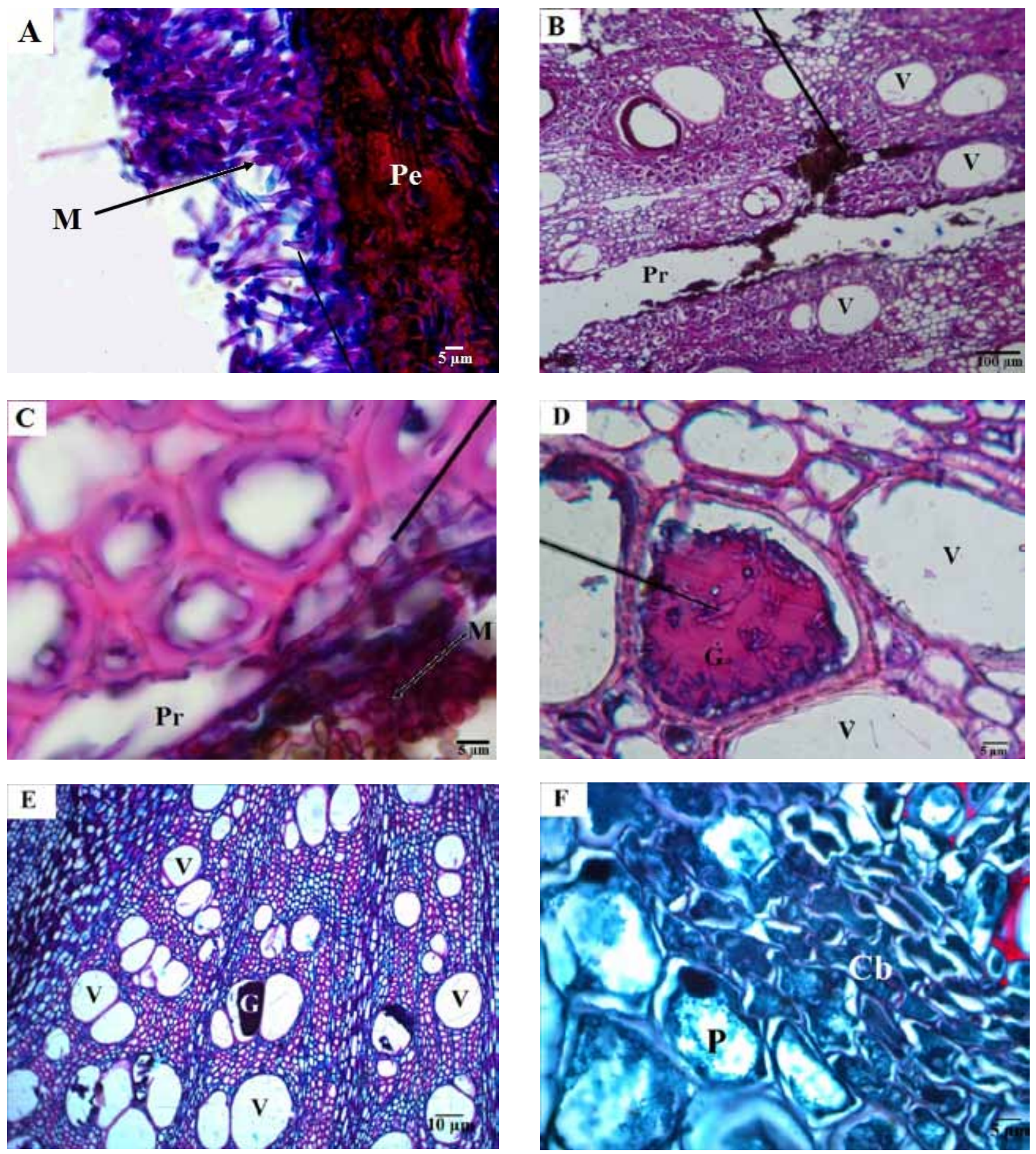

Figure 3. Natural and induced infections of Fusarium solani in purple passionfruit plants. Natural infections in nine-month-old plants (A - E), induced infections at $90 \mathrm{dpi}(\mathrm{F})$. Cross-sections of the collar (A-D, F) and stem (E). The tip of the indicator shows conidiophore (A), pathogen structures (B), hyphae (C) and hyphal tip (D). A-E, PAS staining; F, safranin - fast green staining. V, xylem vessels; Pr, ray parenchyma cells; Pe, periderm; Cb, cambium; P, phloem; M, microconidia; G gel. A, C, D, F: 100X; B: 10X; E: 40X.

results reported for this type of staining (7).

The histological response of induced infections was similar to that of natural infections in the collar, and the hypertrophy and hyperplasia reaction in the cambium cells was pronounced (Figure 3F). However, unlike natural infections, the presence of hyphae and gels could be detected in the lumens of vessels within the stem.

\section{DISCUSSION}

F. oxysporum colonization was observed for all organs of the analyzed purple passionfruit plants (root, stem and collar). This finding corroborates the reported ability of the pathogen to penetrate the root system and colonize the plant through its vascular system. The process of colonization through the vascular system has been documented for 
tomato and pea cultivars susceptible to $F$. oxysporum (4).

Collar infections have shown that $F$. solani colonization occurs from the periderm to the pith through the ray parenchyma cells. A similar response has been reported for infections caused by mutants of $N$. haematococca ( $F$. solani f.sp. pisi) in peas, in which, after penetrating the epidermis, the fungi colonize the cortical parenchyma and inter- and intracellular growth occurs, with radial advancement of the hyphae (24). Parenchyma cells act as a path that facilitates the movement of the pathogen, but other authors have reported that the parenchyma can also act as a defense mechanism that restricts lateral colonization by the compartmentalization processes (23).

There was no evidence of fungal structures in the stem tissue naturally infected with $F$. solani. This finding supports the idea that this pathogen tends to be located in the collar, which is associated with the symptoms observed in the field. Nevertheless, other induced infections could be detected due to the pathogen structures in the stem (data not shown), indicating possible colonization through the xylem. Similarly, studies have mentioned that after disintegration of the vascular parenchyma, colonization of the vascular system occurred (24).

In injuries caused by the pathogens $F$. oxysporum and F. solani, hyphae and microconidia are evident in the lumen of vessels, as well as the formation of gels, which constitutes a defense response of infected plants. Gel formation could limit fungal spread by occluding the vessels; in this study, gels associated with hyphae in the lumen of vessels were frequently observed.

Alterations in the cambium associated with hypertrophy and hyperplasia during infection with $F$. solani could generate the morphological changes observed for xylematic parenchyma cells. Histopathological studies of Fusarium wilt have suggested that the disorders occurring in tissues outside the xylem are due to an apparent reaction to changes in the cambium cells (16). Meanwhile, phloem cells also changed during cell differentiation due to the invasion by these pathogens. Hypertrophy of the vascular parenchyma cells may be an important part of defense (2); proliferation of this type of cell may involve the production of growth-promoting substances, including ethylene (16).

Another consistent response was the reduced amyloplasts in parenchyma cells. This finding could be a mechanism by which the plant depletes carbohydrates present in amyloplasts due to the stress effect produced by the pathogen. In trials with $F$. oxysporum f.sp. tulipae, gradual degradation of starch granules in infected tulip bulbs was observed (22). Additionally, the change in the shape of fiber walls, especially in the root tissue, suggests lignin degradation processes. Studies on the biochemical characteristics of $F$. oxysporum have demonstrated enzymatic activity to degrade cell walls in carnation (14).

Finally, when we compared the results of the different stains used in this study, there was evidence that the techniques of astra blue, basic fuchsin and PAS allow differentiation between pathogen structures, cell organelles and histological defense structures of the plant; however, astra blue-basic fuchsin double staining offers better resolution.

\section{ACKNOWLEDGEMENTS}

We thank the Ministry of Agriculture of Colombia, Horticultural Association of Colombia (Asohofrucol) and Universidad Nacional de Colombia for supporting this study. The authors are also grateful to the Laboratory of Plant Pathology, Faculty of Agronomy and Mr.
Wadith de León for technical support; the Laboratory of Anatomy and Plant Tissue Culture and the Laboratory of Plant Physiology and Biochemistry, Department of Biology, Faculty of Science, National University of Colombia.

\section{REFERENCES}

1. Bancroft, J.; Stevens, A. Theory and practice of histological techniques. 2nd Ed. NY. Churchill Livingstone. 1982. 212 p.

2. Beckman, C. H. The nature of wilt diseases of plants. St. Paul, MN. The American Phytopathological Society. APS Press. 1987. 175 p.

3. Beckman, C. H.; Roberts, E. M. On the Nature and Genetic Basis for Resistance and Tolerance to Fungal Wilt Diseases of Plants. In: Andrews, J.H.; Tommerup, I.C. (Ed.) Advances in Botanical research. Incorporating Advances in Plant Pathology London: Academic Press. 1995. V. 21. p. 36-72.

4. Bishop, C. D.; Cooper, R. M. An ultrastructural study of vascular colonization in three vascular wilt diseases I. Colonization of susceptible cultivars. Physiological and molecular plant pathology, Amsterdam, v. 23, n.3, p. 323-343. 1982

5. Castaño-Zapata, J. Enfermedades importantes de las pasifloráceas en Colombia. In Miranda, D.; Fischer, G.; Carranza, C.; Magnitskiy, S.; Casierra-Posada, P.; Piedrahita, W.; Flórez, V. (Ed.). Cultivo, poscosecha y comercialización de las Pasifloráceas en Colombia: maracuyá, granadilla, purple passion fruit y curuba. Bogotá: Sociedad Colombiana de Ciencias Hortícolas. 2009. p.223-244.

6. Cole, D. L.; Hedges, T. R.; Ndowora, T. A wilt of passion fruit (Passiflora edulis f. edulis Sims) caused by Fusarium solani and Phytophthora nicotianae var. parasitica. Tropical Pest Management, Florida, v. 38,n. 4, p. 362-366. 1992

7. Conn, H. J. Biological stain. 6th. ed. Geneva: Commission on standardization of biological stain. Biotech Publications. 1953. 367p.

8. Fischer, I. H.; Lourenco, S. A.; Martins, M. C.; Kimati, H.; Amorim, L. Seleção de plantas resistentes e de fungicidas para o controle da podridão do colo do maracujazeiro causada por Nectria haematococca. Fitopatologia Brasileira, Brasília, v. 30, n.3, p.250-258. 2005.

9. Fischer, I. H.; Rezende, J. A. Diseases of passion flower (Passiflora sp.). Pest Technology, Tunisia, v.2, n.1, p.1-19, 2008.

10. Gardner, D. Pathogenicity of Fusarium oxysporum f. sp. passiflorae to Banana Poka and other Passiflora spp. in Hawaii. Plant Disease, St. Paul, v.73, n.6, p. 476-478, 1989

11. Kraus, J. E.; Sousa, H. C.; Rezende, M. H.; Castro, N. M.; Vecchi, C.; Luque, R. Astra Blue and Basic Fuchsin Double Staining of Plants Materials. Biotechnic and Histochemistry, London, v.73, n.5, p. 235-243,1998.

12. McKnight, T. A wilt disease of the passion vine (Passiflora edulis) caused by a species of Fusarium. Queensland Journal of Agricultural Science, Queensland, v.8, p. 1-4. 1951.

13. Mendgen, K.; Hahn, M.; Deising, H. Morphogenesis and mechanisms of penetration by plant pathogenic fungi. Annual Review of Phytopathology, Palo Alto, v. 34, p.364-386.1996.

14. Niemann, G.J.; Boon, J.J.; Pureveen, J.B.; Eijkel, G.; Van der Heijden, E. A microanalytical approach to plant tissue characterization: A comparative study of healthy and fungus-infected carnation by pyrolisis mass spectrometry. Journal of Analytical and Applied Pyrolysis, Riverport Lane v.19, p.213-236. 1991.

15. Ortiz, E.; Hoyos-Carvajal, L.M. Caracterización patogénica de aislamientos de Fusarium oxysporum provenientes de cultivos de purple passion fruit en la región del Sumapaz. Fitopatología Colombiana, Palmira, v. 35, p. 45, 2011.

16. Ouellette, G.; Mohamed, C.; Simard, M. Histopathology of Fusarium wilt of staghorn sumac (Rhus typhina) caused by Fusarium oxysporum f.sp. callistephi race 3. III. Host cell and tissue reactions. Phytoprotection, Quebec,v.87, n.1, p. 17-27, 2006.

17. Pegg, K. G.; Willingham, S. L.; O’Brien, R. G. O.; Cooke, A. W.; Coates, L. M. Base rot of golden passion fruit caused by a homothallic strain of Fusarium solani. Australasian Plant Pathology, New York, v.31, n.3, p. 305-306. 2002.

18. Ploetz, R. C. Sudden wilt of passion fruit in southern Florida caused by 
Nectria haematococca. Plant Disease, St. Paul, v.75, p.1071-1073.1991.

19. Ploetz, R. C. Diseases of tropical fruit crops. Wallingford:CABI Publishing, 2003. 527p.

20. Ploetz, R. C. Fusarium-Induced Diseases of Tropical, Perennial Crops. Phytopathology, St. Paul, v. 96, n.6, p.648-652. 2006

21. Ponte, J .J. As doencas do maracujá-amarelo no nordeste do Brasil. Revista Brasilera de Fruticultura, Cruz das Almas, v.15, n.2, p.11-14, 1993.

22. Saniewska, A.; Dyki, B.; Jarecka, A. Morphological and histological changes in tulip bulbs during infection by Fusarium oxysporum f.sp. tulipae. Phytopathologia Polonica, Poznan, v.34, p.21-39, 2004.
23. Shigo, A. L.; Marx, H. G. Compartmentalization of decay in trees. Agricultural information Bulletin 405. Washington DC: Department of Agriculture, Forest Service. 1977. $73 \mathrm{p}$

24. Stahl, O.; Theuerkauf, A.; Heitefuss, R.; Schäfer, W. Cutinase of Nectria haematococca (Fusarium solani f. sp. pisi) is not required for fungal virulence or organ specificity on pea. Molecular Plant Microbe Interactions, St. Paul, v.7, n.6, p.713-725, 1994.

25. Vakalounakis, D. J. Root and stem rot of cucumber caused by Fusarium oxysporum f. sp. radicis-cucumerinum f. sp. nov. Plant Disease, St. Paul, v.80, p.313-316. 1996. 